\title{
Ondansetron and psychiatry, behind de mechanisms of gastrointestinal and nervous system serotonin
}

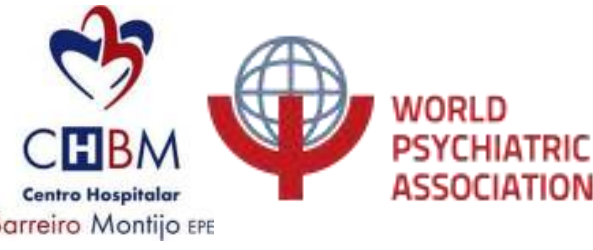

\section{Objective}

Our main objective is to look for potential augmentation strategies in psychiatric conditions with a $5 \mathrm{HT} 3$ antagonist ondansetron

\section{Materials and methods}

A non systematic literature search was performed in pubmed, medline and uptodate, using the key words "ondansetron psychiatry".

\section{Serotonin}

Serotonin is a neurotransmitor that ats both in nervous system and gastrointestinal track

Ascending serotonin projections

Extend to prefrontal cortex, basal forebrain, thalamus, hypotalamus, amygdala, hipocampus, striatum and nucleus accumbens

Regulation of mood, anxiety, sleep, congnition

\section{Descending serotonin projections}

Extend to brainstem and spinal cord.

\section{Co-related with pain, visceral} regulation, motor control

5HT3 receptors (Ionic channels) are localized in:

chemoreceptor trigger zone of the brainstem

-Where they mediate nausea and vomiting,

\section{the gastrointestinal tract}

- Where they mediate nausea, vomiting, and diarrhea/ bowel motility when stimulated.

- Blocking these receptors can therefore protect against serotonin-induced gastrointestinal side effects that often accompany agents that increase $5 \mathrm{HT}$ release.

\section{the brain}

- Where regulate inhibitory GABA interneurons in various brain areas that in turn regulate the release of a number of neurotransmitters, from serotonin itself to acetylcholine, norepinephrine, dopamine, and histamine.

- Serotonin acting at 5HT3 receptors reduces the release of these neurotransmitters

- Blocking 5HT3 receptors causes disinhibition of these

\section{Results}

\section{- Alcool Dependence}

- Myrick et al 2008

- $\mathrm{N}=90$

- double-blind randomly assigned daily dosing with

- $50 \mathrm{mg}$ of naltrexone $(\mathrm{n}=23)$, $0.50 \mathrm{mg}$ of ondansetron hydrochloride $(n=23)$, the combination of the 2 medications $(n=20)$, or matching placebos $(n=24)$

- Ondansetron by itself was similar to naltrexone and the combination in the overall analysis

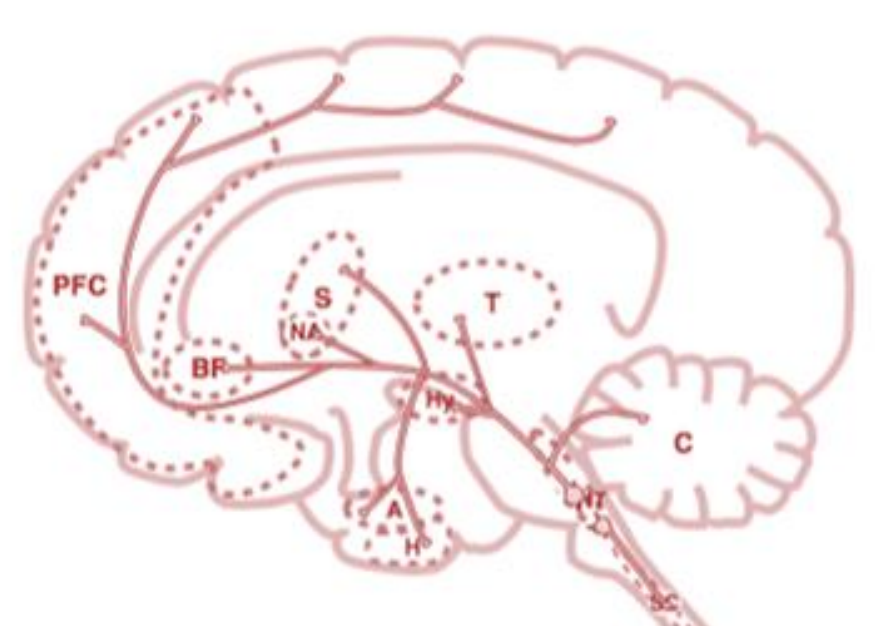

Ondansetron:

5HT3 receptor antagonist

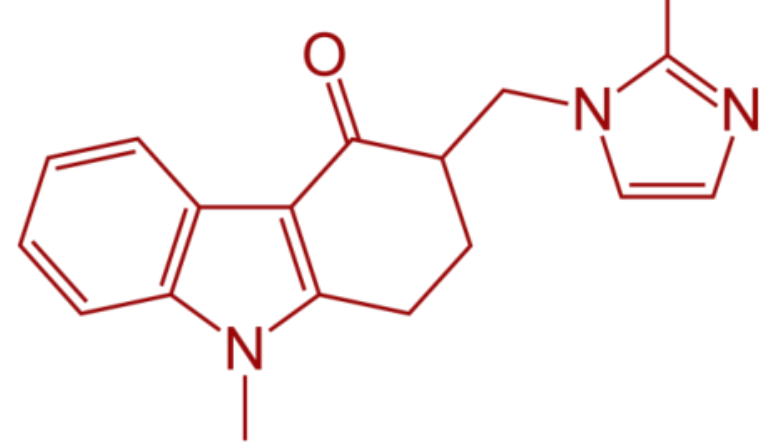

\section{Results}

\section{- Schizophrenia}

\section{Johnson et al 2000}

Randomized controlled trial

\section{$\mathrm{N}=321$}

11 weeks of treatment with ondansetron: 1 microg/kg $(n=67)$, $4 \mathrm{microg} / \mathrm{kg}(\mathrm{n}=77)$, or 16 microg/kg ( $=71)$ twice per day; or placebo $(n=56)$.

- Ondansetron was superior to placebo in fewer drinks per day and increasing percentage of days abstinent
- Kulkarni J et al 2018

- randomized control trial

\section{$\mathrm{N}=85$}

schizophrenia patients with antipsicotic were

randonmized in

Ondansetron $8 \mathrm{mg}$ or Placebo

- the improvement was only observed in cognitive symptoms

\section{- Obsessive Compulsive \\ Disorder}

Heidari et al 2015

\section{$\mathrm{N}=46$}

8 week double- blind ondansetron (8 mg/day) fluvoxamine versus placebo - fluvoxamine

Ondansetron showed significant beneficial effect as an augmentative agent with fluvoxamine in patients with moderate to severe OCD and it was generally well tolerated.

\section{Schizophrenia}

Samedi et al 2017

double-blinded, placebocontrolled, randomized trial

- $\mathrm{N}=38$

patients with treatmentresistant schizophrenia received risperidone either combined with a fixed dose (4-8 $\mathrm{mg} / \mathrm{d}$ ) of ondansetron $(n=18)$ or with a placebo $(n=20)$ for 12 weeks benefits for both cognitive and negative symptoms.

\section{Obsessive Compulsive} Disorder

- Pallanti et al 2014

$\mathrm{N}=21$

OCD patients who had not responded adequately to an SRI received 12 weeks of single-blind ondansetron augmentation

- At week 12, twelve of the 21 $(57 \%)$ patients were responders

$\begin{array}{lll}\text { - Anxiety } & \text { - Depression } \\ \text { - Freeman at al } 1997 & \text { - } \text { Bétry C et al } 2016\end{array}$

- Freeman at al 1997 - Rats, treated with

Double-blind, placebocontrolled, randomized ondansetron, and/or a subeffective dose of paroxetine were assessed in the forced swim test.

\section{ondansetron $1.0 \mathrm{mg}$ bid} showed a significant reduction in anxiety symptoms (mean HARS score) compared to placebo.
- The results showed that ondansetron enhanced the antidepressant activity of paroxetine in the forced swim test

That 5-HT3 receptor blockade potentiates the antidepressant effects of SSRIs 